\title{
EFEKTIVITAS PENYALURAN KREDIT USAHA RAKYAT PT. BRI (PERSERO) UNIT BLAHKIUH TERHADAP PRODUKTIVITAS UKM DAN PENDAPATAN UKM PENERIMA KUR DI KECAMATAN ABIANSEMAL
}

\author{
Ni Luh Made Ayu Danni Lastina ${ }^{1}$ \\ Made Kembar Sri Budhi \\ ${ }^{1,2}$ Fakultas Ekonomi dan Bisnis Universitas Udayana (Unud), Bali, Indonesia \\ Email : ayudannilastina@yahoo.com
}

\begin{abstract}
ABSTRAK
Penelitian ini bertujuan untuk mengetahui efektivitas penyaluran kredit usaha rakyat Bank BRI (Persero) Unit Blahkiuh terhadap produktivitas UKM dan pendapatan UKM penerima KUR di Kecamatan Abiansemal. Alat analisis yang digunakan adalah analisis SEM Partial Least Square (PLS). Penelitian ini menggunakan jenis data primer dan pengumpulan data dilakukan melalui penyebaran kuesioner kepada UKM yang mengambil KUR di Bank BRI Unit Blahkiuh sebanyak 100 responden. Hasil analisis menunjukkan (i) Efektivitas penyaluran KUR Bank BRI Unit Blahkiuh berpengaruh positif dan signifikan terhadap produktivitas UKM di Kecamatan Abiansemal. (ii) Produktivitas UKM berpengaruh positif dan signifikan terhadap pendapatan UKM di Kecamatan Abiansemal. (iii) Efektivitas penyaluran KUR Bank BRI Unit Blahkiuh berpengaruh positif dan signifikan terhadap pendapatan UKM melalui produktivitas UKM di Kecamatan Abiansemal.

Kata kunci : Efektivitas, Produktivitas dan Pendapatan
\end{abstract}

\begin{abstract}
This study aims to determine the effectiveness of business credit distribution of Bank BRI (Persero) Unit Blahkiuh to SME productivity and SME revenue recipient KUR in District Abiansemal. Analyzer used is SEM analysis of Partial Least Square (PLS). This study uses primary data types and data collection is done through the distribution of questionnaires to SMEs who take KUR at Bank BRI Unit Blahkiuh as much as 100 respondents.The analysis results show (i) The effectiveness of KUR distribution of Bank BRI Unit Blahkiuh has a positive and significant effect on SME productivity in Abiansemal Sub-district. (ii) SME productivity has a positive and significant impact on SME revenue in Abiansemal Sub-district. (iii) The effectiveness of KUR distribution of Bank BRI Unit Blahkiuh has a positive and significant effect on SME revenue through SME productivity in Kecamatan Abiansemal.
\end{abstract}

Keywords: Effectiveness, Productivity and Income 
Ni Luh Md. Ayu Danni Lastina, dan Md. Kembar Sri Budhi. Efektifitas Penyaluaran......

\section{PENDAHULUAN}

Usaha Kecil dan Menengah disingkat UKM adalah sebuah istilah yang mengacu ke jenis usaha kecil yang memiliki kekayaan bersih paling banyak Rp 200.000.000 tidak termasuk tanah dan bangunan tempat usaha. Dan usaha yang berdiri sendiri. Keppres RI no. 99 tahun 1998 tentang pengertian Usaha Kecil ialah kegiatan ekonomi rakyat yang berskala kecil dengan bidang usaha yang secara mayoritas merupakan kegiatan usaha kecil dan perlu dilindungi untuk mencegah dari persaingan usaha yang tidak sehat.

Keberadan UKM di Indonesia sudah terbukti mampu untuk menjadi roda penggerak ekonomi di masa krisis. UKM dapat diartikan sebagai penyelamat dalam pembangunan ekonomi pasca krisis sebab UKM mampu mengurangi tingkat pengangguran dan memberikan kesempatan kerja serta dapat berperan dalam pendistribusian hasil pembangunan (Baholi.2015). UKM bisa dikatakan salah satu sektor yang mempengaruhi perekonomian (Saleh.2006). Disamping itu, UKM menghadapi permasalahan seperti halnya modal usaha yang terbatas, sumber daya manusia yang belum memenuhi syarat, dan serta kurangnya penguasaan terhadap teknologi (Sudaryanto dan Hanim, 2002). Berikut Tabel 1.1 mengenai jumlah UKM di Kabupaten Badung Tahun 2016.

\section{Tabel 1}

Jumlah UKM Kabupaten Badung 2016

\begin{tabular}{cccc}
\hline No & Nama Kecamatan & Jumlah & Persentase \\
\hline 1 & Kuta Selatan & 2187 & 11.02 \\
2 & Kuta Tengah & 2364 & 11.91 \\
3 & Kuta Utara & 2509 & 12.64 \\
4 & Mengwi & 5103 & 25.72 \\
5 & Abiansemal & 5589 & 28.17 \\
6 & Petang & 2087 & 10.51 \\
Jumlah Pengusaha UKM & 19.839 & 100.00 \\
\hline
\end{tabular}


Sumber : Dinas Koperasi, UKM, Perindustrian, dan Perdagangan Kabupaten Badung 2016 (data diolah)

Berdasarkan Tabel 1.1 Kecamatan Abiansemal menempati urutan pertama dari jumlah UKM tertinggi di Kabupaten Badung dan urutan selanjutnya oleh kecamatan Mengwi, Kuta Utara, Kuta Tengah, Kuta Selatan, dan Petang. Hal ini menunjukkan semakin besar kesempatan bagi Bank BRI Unit Blahkiuh dalam penyaluran dana KUR untuk membantu permodalan di Kecamatan Abiansemal. Menurut Wenagama (2009) pengusaha berskala kecil dapat digolongkan dalam kelompok usaha kecil dan menengah di Kabupaten Badung yang memiliki peranan yang sangat strategis dan berkaitan dengan upaya pembentukan pendapatan masyarakat, serta juga berkaitan dengan terciptanya lapangan pekerjaan yang luas.

Kecamatan Abiansemal terdiri dai 18 desa dengan jumlah penduduk 87.722 jiwa. Pada Tabel 2 menggambarkan mata pencaharian masyarakat di Kecamatan Abiansemal terbanyak terdapat di sektor pertanian sebanyak 23.238 orang, disusul oleh sektor industri sebanyak 13.444 orang, perdagangan sebanyak 13.214 orang dan peternakan sebanyak 5.272 orang. Menurut Palazuelos (2008) meskipun jumlah masyarakat dengan mata pencaharian sebagai pedagang dan industri lebih kecil bila dibandingkan sektor pertanian namun dalam hal ini tidak menutup kemungkinan menjadi kesempatan untuk menyalurkan dana KUR Bank BRI Unit Blahkiuh di Kecamatan Abiansemal guna menunjang peningkatan produktivitas serta pendapatan dari sektor perdaganan dan industri di Kecamatan Abiansemal. 
Tabel 2

Mata PencaharianPenduduk di Kecamatan Abiansemal 2016

\begin{tabular}{clcccc}
\hline No & \multicolumn{1}{c}{ Desa } & Pertanian & Perdagangan & Industri & Peternakan \\
\hline 1 & Darmasaba & 3274 & 1599 & 1829 & 457 \\
2 & Sibang Gede & 2297 & 854 & 896 & 221 \\
3 & Jagapati & 668 & 612 & 439 & 112 \\
4 & Angantaka & 1069 & 352 & 515 & 125 \\
5 & Sedang & 1249 & 374 & 554 & 132 \\
6 & Sibang Kaja & 1199 & 1403 & 999 & 204 \\
7 & Mekar Bhuana & 1015 & 853 & 939 & 110 \\
8 & Mambal & 1016 & 1006 & 873 & 652 \\
9 & Abiansemal & 1015 & 1076 & 655 & 807 \\
10 & Dauh Yeh Cani & 1300 & 1277 & 915 & 220 \\
11 & Ayunan & 496 & 336 & 412 & 153 \\
12 & Blahkiuh & 1321 & 1139 & 776 & 236 \\
13 & Punggul & 957 & 167 & 481 & 232 \\
14 & Bongkasa & 2108 & 541 & 728 & 479 \\
15 & Taman & 1164 & 362 & 1497 & 432 \\
16 & Selat & 991 & 197 & 204 & 203 \\
17 & Sangeh & 997 & 732 & 432 & 315 \\
18 & Bongkasa Pertiwi & 624 & 334 & 309 & 182 \\
& Jumlah & 23238 & 13214 & 13444 & 5272 \\
\hline
\end{tabular}

Sumber : Badan Pusat Statistik Kabupaten Badung 2016

Tingginya pertumbuhan dan peranan UKM di Bali khususnya di Kecamatan Abiansemal masih terkendala masalah produktivitas dan permodalan (Diskopperindag Badung,2016). Menurut Surya (2012) tingkat produktivitas yang rendah akan berdampak pada pelaku usaha, sehingga akan menimbulkan kendala yang harus segera ditangani. Apabila hal tersebut tidak segera ditangani, maka akan berdampak negatif terhadap pendapatan dan perkembangan usaha (Bonifrm.2003). Menurut penelitian yang dilakukan Ade (2011) tentang pengaruh jumlah kredit terhadap produktivitas UKM di Kota Denpasar menunjukkan bahwa salah satu variabel yang mempengaruhi efektivitas penggunaan kredit adalah jumlah kredit yang diberikan kepada UKM. Gaspersz (2001) menyatakan bahwa produktivitas ialah perilaku mental yang mempunyai pandangan bahwa hari ini harus lebih baik dari hari kemarin. 
Menurut Artis (2012) dalam kenyataan yang terjadi masyarakat menengah kebawah tidak keseluruhan memiliki modal usaha yang memadai guna untuk memulai atau meningkatkan perkembangan usahanya tersebut serta produktivitasnya, sehingga masyarakat menengah kebawah ini memerlukan bantuan modal yang berupa pinjaman atau kredit, salah satunya disuatu lembaga perbankan. Dengan adanya permasalahan yang dihadapi UKM, pemerintah berupaya untuk mengurai masalah tersebut dengan mengeluarkan program Kredit Usaha Rakyat (KUR). Sesuai dengan Inpres No. 6 tahun 2007 tanggal 8 juni 2007 tentang kebijakan percepatan pengembangan sektor riil dan pemberdayaan UKM serta notakesepahaman bersama antara pemerintah, perbankan dan perusahaan penjamin pada tanggal 9 oktober 2007, pemerintah telah meluncurkan program Kredit Usaha Rakyat (KUR). Sasaran utama dari program ini adalah Usaha Kecil dan Menengah (UKM) atau untuk rakyat Indonesia yang produktif.

Salah satu faktor yang dapat meningkatkan pendapatan ialah besarnya modal usaha (Curak.2013). Dalam memulai sebuah usaha, salah satu yang paling penting yang dibutuhkan adalah modal . Modal adalah dana yang harus dikeluarkan untuk menghasilkan barang atau jasa yang dihasilkan seseorang (Issabella, 2015). Tanpa adanya modal usaha seseorang belum bisa menyelesaikan pembuatan barang dan jasa sesuai permintaan. Jadi tanpa modal usaha seseorang tidak akan mendapatkan pembeli karena tidak ada barang dan jasa yang dihasilkan. Untuk menaikkan hasil produksi barang dan jasa tidak cukup dengan menggunakan modal sendiri (Hue 2015). Maka dari itu perlu adanya pinjaman modal dari pihak lain,seperti 
Ni Luh Md. Ayu Danni Lastina, dan Md. Kembar Sri Budhi. Efektifitas Penyaluaran......

pinjaman modal dari bank khususnya dalam penelitian ini ialah pinjman modal dari KUR BRI Unit Blahkiuh.

Menurut Anggraini (2013) bahwa semakin besar jumlah modal KUR yang diperoleh oleh UKM di Kota Medan, maka semakin tinggi tingkat pendapatan yang akan diperoleh UKM, begitu juga sebaliknya. Namun disisi lain menurut penelitian Mahmudah (2015) menyatakan bahwa semakin baik modal pinjaman KUR yang diambil oleh UKM di Unit Laren Kabupaten Lamongan, maka penghasilan UKM juga akan mengalami peningkatan. Serta hasil penelitian Saragih dan Nasution (2015) menunjukkan bahwa pendapatan pengusaha UKM Kabupaten Toba Samosir dipengaruhi oleh besar kecilnya modal sendiri (awal) dan modal pinjaman KUR yang diterima.

\section{Tabel 3}

Tingkat Pendidikan Masyarakat Kecamatan Abiansemal

Tahun 2012-2016

\begin{tabular}{lccccc}
\hline \multicolumn{1}{c}{ Tingkat } & \multicolumn{5}{c}{ Tahun } \\
\cline { 2 - 6 } \multicolumn{1}{c}{ Pendidikan } & 2012 & 2013 & 2014 & 2015 & 2016 \\
\hline SD & 97.71 & 103.04 & 102.82 & 102.06 & 101.84 \\
SMP & 94.90 & 105.44 & 100.26 & 94.24 & 96.75 \\
SMA & 105.18 & 74.35 & 85.79 & 98.75 & 99.23 \\
Perguruan Tinggi & 20.52 & 25.63 & 28.40 & 33.81 & 46.12 \\
\hline Sumber : BPS Kabupaten Badung 2016 & & & &
\end{tabular}

Berdasarkan Tabel 1.3 menunjukkan tingkat pendidikan yang dimiliki masyarakat di Kecamatan Abiansemal, dimana masyarakatnya lebih banyak menyelesaikan pendidikannya sampai tingkat sekolah dasar. Triwibowo (2009) tingkat pendidikan termasuk dalam karakteristik personal debitur. Dalam penelitian Asih (2007) tingginya tingkat pendidikan pengusaha menjadi landasan atau dasar dalam memahami dan berpikir, hal ini akan mempengaruhi kemampuan dalam mengelola usahanya. Menurut Candra (2016) rendahnya tingkat pendidikan 
akan mempengaruhi penggunakan kredit yang disalurkan secara langsung dan mempengaruhi perkembangan UKM yang ada di Denpasar.

Tingkat pendidikan dapat mempengaruhi kemampuan masyarakat dalam mempertimbangkan dan mengambil keputusan untuk menentukan jumlah kredit yang diambil untuk menambah biaya hidup, maka dengan kemampuan yang dimiliki, masyarakat mempunyai kemauan untuk mengambil kredit yang dibutuhkan (Rajan.2003). Tingkat pendidikan untuk tenaga kerja adalah salah satu usaha untuk pembagian kerja untuk meningkatkan produktivitas kerja serta dalam pengelolaan keuangan (Shingjergji.2013). Tingkat pendidikan berpengaruh bagi seseorang dalam menjalankan usaha. Masyarakat khususnya UKM yang berpendidikan tinggi mempunyai kemampuan yang lebih baik dalam menggunakan teknologi dan dapat dengan cepat menangkap celah pasar sehingga berdampak pada produktivitas yang tinggi (Desiderius, 2009).

Menurut Eko (2009) dalam penelitiannya menyatakan tingkat pendidikan adalah faktor yang mempengaruhi permintaan KUR dimana semakin tinggi tingkat pendidikan seseorang, maka usaha yang dijalankan dalam jumlah yang besar sehingga mengakibatkan perlunya pinjaman modal untuk perkembangan dan perluasan usahanya. Menurut Todaro (2000) bahwa seseorang dapat meningkatkan penghasilan melalui peningkatan pendidikan, setiap tambahan satu tahun sekolah berarti disatu pihak meningkatkan kemampuan kerja dan tingkat penghasilan seseorang. Karena dalam pengalokasian sumber daya manusia akan diserap oleh lapangan kerja (Fadhilah Rahmawati, dkk, 2004). 
Ni Luh Md. Ayu Danni Lastina, dan Md. Kembar Sri Budhi. Efektifitas Penyaluaran......

Menurut Andriani (2008) untuk peningkatan jaminan di perusahaan penjamin, pemerintah perlu mempertimbangkan beberapa hal sebab pengalokasian dana pinjaman tersebut bersumber dari APBN. Oleh karena itu, peningkatan besaran jaminan di berbagai perusahaan penjamin untuk KUR seharusnya menjadi prioritas guna mengelola anggaran, sehinggan KUR ini mampu bisa mencapai tujuannya (Henny, 2015).

\section{Tabel 4}

Realisasi dan Jumlah Debitur KUR PT.Bank BRI Unit Blahkiuh

Tahun 2015 - 2016

\begin{tabular}{lcc}
\hline \multicolumn{1}{c}{ Bulan } & Realisasi KUR (Rupiah) & $\begin{array}{c}\text { Realisasi Jumlah Debitur } \\
\text { (Orang) }\end{array}$ \\
\hline 31 Desember 2015 & 3.962 .414 .100 & 302 \\
31 Januari 2016 & 5.995 .675 .349 & 400 \\
Februari 2016 & 8.067 .926 .108 & 504 \\
31 Maret 2016 & 9.463 .781 .355 & 576 \\
30 April 2016 & 11.275 .089 .079 & 672 \\
31 Mei 2016 & 12.229 .117 .041 & 733 \\
30 Juni 2016 & 12.978 .994 .257 & 791 \\
31 Juli 2016 & 13.070 .476 .764 & 823 \\
31 Agustus 2016 & 13.157 .900 .773 & 860 \\
30 September 2016 & 13.187 .671 .010 & 969 \\
31 Oktober 2016 & 13.235 .002 .846 & 997 \\
30 November 2016 & 13.293 .532 .300 & 1125 \\
31 Desember2016 & 13.400 .304 .764 & 1254 \\
\hline
\end{tabular}

Sumber : Bank Bri Unit Blahkiuh Tahun 2015-2016

Berdasarkan Tabel 3 tingkat perkembangan KUR pada Tahun 2015 akhir dan 2016 di Bank BRI unit Blahkiuh di Kecamatan Abiansemal terus mengalami kenaikkan setiap bulannya serta kenaikan yang terjadi pada bulan Desember 2015 hingga bulan Desember 2016 sangat tinggi, hal ini terjadi karena penyaluran dana KUR berfokus pada kelompok mikro seperti UKM. Ini berarti menunjukkan perkembangan penyaluran KUR cukup berkembang dan diminati para UKM di Kecamatan Abiansemal. Tingginya pengaruh UKM dalam perekonomian nasional dan daerah khususnya di Kecamatan Abiansemal, seharusnya mendapatkan 
perhatian yang lebih terhadap keberadaan UKM guna untuk penguatan ekonomi kerakyatan di Provinsi Bali. Dengan demikian diharapkan agar pemberian Kredit Usaha Rakyat (KUR) dapat meningkatkan pendapatan pelaku usaha atau UKM.

Bank BRI Unit Blahkiuh sendiri merupakan bank yang dalam penyaluran pinjamannya cukup meningkatkan setiap bulan untuk pencapaian targetnya. Adanya beberapa aspek kelayakan usaha yang menjadi syarat untuk mendapatkan KUR yang bertujuan agar dana yang di terima tidak menjadi kredit macet karena keterlambatan pembayaran atau pelunasan pinjaman. Selain itu penyaluran kredit dikatakan produktif jika kredit yang disalurkan kepada UKM yang diberikan benar-benar digunakan untuk pembiayaan sebagaimana yang dicantumkan dalam proposal kreditnya. Pemberian kredit mempunyai tingkat resiko kredit yang tinggi bagi bank karena memiliki biaya dana yang cukup tinggi pula untuk membiayainya (Tracey.2011). Keterlambatan pengembalian kredit akan merugikan pihak bank, modal menjadi beku dan menurun serta berkurangnya pendapatan yang mestinya diperoleh dari hasil pemberian kredit.

Efektivitas ialah suatu sasaran atau tujuan yang telah dicapai sesuai dengan apa yang telah direncanakan. Menurut Yhushinta (2006) efektivitas adalah suatu program yang dapat diartikan sebagai tingkat kemampuan suatu program untuk mewujudkan hasil yang ingin dicapai sesuai dengan tujuan dan sasaran yang telah ditetapkan, begitu juga dengan efektivitas KUR, efektivitas program KUR bisa dilihat dari besarnya alokasi penyaluran kredit dan sangat tergantung pada distribusi pengalokasiannya, baik menurut sektor ekonomi maupun penerimanya (pelaku ekonominya). 
Ni Luh Md. Ayu Danni Lastina, dan Md. Kembar Sri Budhi. Efektifitas Penyaluaran......

Menurut Anugrah (2013) Indikator efektivitas dalam penyaluran kredit meliputi berhasil atau tidaknya seseorang atau suatu organisasi untuk mencapai suatu tujuan dalam penyaluran kredit, adanya perkembangan dan pertumbuhan yang dialami seseorang ketika adanya penyaluran kredit, dan adanya perbedaan positif secara signifikan antara apa yang diharapkan dengan apa yang terjadi (sebelum atau sesudah) dalam penyaluran kredit. KUR yang disalurkan BRI Unit Blahkiuh diharapkan akan mampu mengatasi masalah UKM di Kecamatan Abiansemal. Menurut Anggiawan (2010) realisasi pembiayaan harus bersifat efektif yaitu mudah dalam prosedurnya dan tidak membutuhkan waktu yang lama dalam pencairannya. Sehingga di perlukan faktor utama yang dapat mendukung cepat dan mudah dalam perealisasian pembiayaannya. Prosedur pelaksanaan penyaluran KUR bagi beberapa UKM atau masyarakat tidak mudah. Ada beberapa persyaratan yang harus dipenuhi karena sebagian besar debitur dalam penggunaan modal usahanya sering menyimpang dari alasan pada saat mengajukan kredit atau KUR.

Menurut Jeriko Boyke (2014) ada kasus lain yang menjadi sorotan adalah adanya sebagian pelaku usaha yang meminjam bantuan KUR tersebut, tetapi tidak menggunakan bantuan tersebut sebagai modal usaha, tetapi untuk hal-hal lain yang tidak ada kaitannya dengan usaha yang dijalani, sehingga membuat pelaku usaha tersebut sulit dalam melakukan pembayaran kewajiban kepada bank pelaksana peminjam modal tersebut. Berdasarkan fenomena dan tinjauan teoritis dan empiris seperti latar belakang maka penelitian ini dilakukan untuk mengukur efektivitas penyaluran KUR BRI terhadap produktivitas UKM dan pendapatan 
UKM di Kecamatan Abiansemal. Untuk mengukur dan mengetahui efektivitas penyaluran KUR dalam penelitian ini menggunakan indikator yang terdiri dari jenis usaha, lama usaha, pendidikan, umur, dan variabel produktivitas, dan pendapatan UKM.

Penelitian ini memiliki tujuan antara lain (1) Untuk mengetahui pengaruh efektivitas penyaluran KUR Bank BRI Unit Blahkiuh terhadap produktivitas UKM penerima KUR di Kecamatan Abiansemal. (2) Untuk mengetahui pengaruh efektivitas penyaluran KUR Bank BRI Unit Blahkiuh terhadap pendapatan UKM di Kecamatan Abiansemal. (3) Untuk mengetahui ada pengaruh tidak langsung efektivitas penyaluran KUR Bank BRI Unit Blahkiuh terhadap Pendapatan UKM penerima KUR melalui produktivitas UKM di Kecamatan Abiansemal.

Hipotesis dalam penelitian ini yaitu : (1) Efektivitas penyaluran KUR Bank BRI Unit Blahkiuh berpengaruh positif dan signifikan terhadap produktivitas UKM di Kecamatan Abiansemal. (2) Efektivitas penyaluran KUR Bank BRI Unit Blahkiuh berpengaruh positif dan signifikan terhadap pendapatan UKM di Kecamatan Abiansemal. (3) Efektivitas penyaluran KUR Bank BRI Unit Blahkiuh berpengaruh secara tidak langsung terhadap pendapatan UKM di Kecamatan Abiansemal melalui produktivitas UKM.

\section{METODE PENELITIAN}

Metode penelitian didalam penelitian ini menggunakan metode kuantitatif, dimana data primer yang diperoleh dari responden memakai kuisioner yang disebarkan. Populasi dalam penelitian ini terdiri dari 1254 debitur yang mendapatankan dana KUR dari Bank BRI Unit Blahkiuh dari tahun 2015 sampai 
Ni Luh Md. Ayu Danni Lastina, dan Md. Kembar Sri Budhi. Efektifitas Penyaluaran......

tahun 2016. Teknik pengambilan sampel dalam penelitian menggunakan stratified random sampling. Dengan tingkat eror 10 persen dan dihitung menggunakan rumus slovin maka sampel yang akan diteliti berjumlah 100 sampel. selanjutnya, metode pengambilan sampel di setiap desa dilakukan dengan menggunakan metode stratified random sampling. Menurut Sugiyono (2010) stratified random sampling adalah teknik yang digunakan bila populasi mempunyai anggota/unsur yang tidak homogen dan berstrata secara proporsional.

Adapun variabel dalam penelitian ini dapat diidentifikasi sebagai berikut: Variabel dependen yang digunakan dalam penelitian ini adalah variabel Pendapatan UKM penerima KUR BRI unit Blahkiuh di Kecamatan Abiansemal. Variabel independen yang digunakan dalam penelitian ini adalah variabel Efektivitas penyaluran KUR Bank BRI Unit Blahkiuh. Variabel intervening yang digunakan dalam penelitian ini adalah Produktivitas UKM.

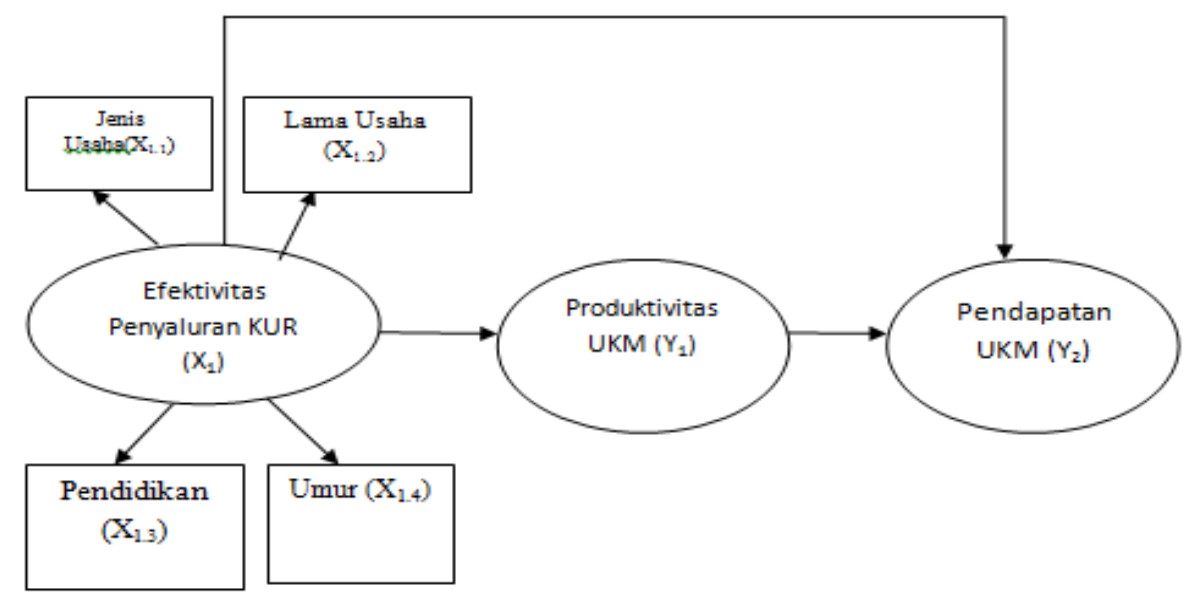

Gambar 1

Konsep Penelitian Efektivitas Penyaluran Kredit Usaha Rakyat Bank BRI Unit Blahkiuh terhadap Produktivitas UKM dan Pendapatan UKM 
Teknik analisis data yang dipakai dalam penelitian ini guna mengetahui pengaruh variabel yang diteliti didalam penelitian adalah teknik Partial Least Square (PLS) dengan menggunakan software Smart PLS 3.0.

\section{HASIL DAN PEMBAHASAN}

Penelitian ini menguji pengaruh Statistik Efektivitas Penyaluran Kredit Usaha Rakyat PT. Bank BRI (Persero) Unit Blahkiuh Terhadap Produktivitas UKM dan Pendapatan UKM Penerima KUR. Secara keseluruhan full Model dari Statistik Efektivitas Penyaluran Kredit Usaha Rakyat PT. Bank BRI (Persero) Unit Blahkiuh Terhadap Produktivitas UKM dan Pendapatan UKM.

Dari hasil analisis model awal diketahui bahwa terdapat 2 indikator variabel dengan nilai loading kurang dari 0.5. Indikator tersebut ialah indikator jenis usaha dengan nilai 0.074 dan indikator pendidikan dengan nilai 0,0485 , maka kedua indikator tersebut harus dibuang atau dieliminasi. Selanjutnya dilakukan pengujian model yang kedua (setelah eliminasi) dengan hasil diagram jalur persamaan seperti gambar 4 yang menunjukkan seluruh indikator memiliki nilai loading $>0,5$. Diagram jalur persamaan struktural inilah yang digunakan untuk melakukan analisi data lebih lanjut.

Pengevaluasian goodness of fit dari outer model (measurement model) menggunakan tiga hal yaitu nilai convergent validity, discriminant validity, dan composite reliability. Perhitungan convergent validity bertujuan guna mengetahui instrumen yang dapat digunakan sebagai indikator dari seluruh konstruk laten. Hasil dari pengujian convergent validity diukur berdasarkan besarnya nilai 
Ni Luh Md. Ayu Danni Lastina, dan Md. Kembar Sri Budhi. Efektifitas Penyaluaran......

loading faktor (outer loading) dari indikator konstruk. Hasil pengujian convergent validity dapat dilihat pada Tabel 5

Tabel 5

Hasil Pengujian Convergent Validity

\begin{tabular}{cccc}
\hline Variabel & Indikator & Outer Loading & Keterangan \\
\hline & $\mathrm{X} 1.2$ & 0.770 & Valid \\
Efektivitas (X1) & $\mathrm{X} 1.4$ & 0.903 & Valid \\
& - & 1.000 & Valid \\
Pendapatan UKM (Y2) & - & & \\
& & 1.000 & Valid \\
\hline
\end{tabular}

Sumber : Data primer 2017

Mindra Jaya dan Sumertajaya (2008) mengatakan bahwa hasil korelasi antara skor indikator reflektif dengan skor variable latennya (convergent validity) antara 0.5 sampai dengan 0.6 dianggap cukup pada jumlah indikator per konstruk tidak besar berkisar antara tiga sampai tujuh indikator. Berdasarkan hasil pengujian pada Tabel 5.7 menunjukkan bahwa ada 2 indikator yang memiliki nilai di bawah 0,50 sehingga tidak valid dan tidak memenuhi persyaratan validitas konvergen, yaitu indikator jenis usaha (X1.1) dan pendidikan (X1.3) sementara indikator lainnya memiliki nilai diatas 0,50 sehingga valid dan memenuhi persyaratan validitas konvergen.

Validitas dalam suatu konstruk juga dapat dilihat dari Discriminant Validity (DV). Discriminant validity pada setiap indikator reflektif ialah dengan 
melihat crossloading indikator terhadap konstruk. DV yang bagus yang mana indikatornya memiliki crossloading pada konstruknya lebih besar dibandingkan dengan konstruk lainnya. Hasil crossloading indikator terhadap konstruk jenis usaha, lama usaha, pendidikan dan umur ada pada Tabel 6. Discriminant validity sudah terpenuhi dengan melihat crossloading sudah terpenuhi dengan baik karena indikatornya memiliki crossloading lebih besar dari pada konstruknya lainnya.

Tabel 6

Crossloading Indikator Penelitian

\begin{tabular}{lccc}
\hline \multicolumn{1}{c}{ Konstruk } & Efektivitas & Pendapatan & Produktivitas \\
\hline Lama Usaha (X1.2) & 0.770 & 0.485 & 0.179 \\
Umur (X1.4) & 0.903 & 0.742 & 0.194 \\
Produktivitas UKM (Y1) & 0.221 & 0.308 & 1.000 \\
Pendapatan UKM (Y2) & 0.752 & 1.000 & 0.308 \\
\hline
\end{tabular}

Data Primer 2017

Uji kelayakan konstruk yang dibuat untuk dapat dilihat dari discriminant validity (DV) melalui Average Variance Extracted (AVE), composite reliability ( $\mathrm{c})$ menggunakan indikator reflektif yang bertujuan untuk mengukur konsistensi internal suatu konstruk, dan Cronbach Alpha. Hasil olah data dapat disajikan pada Tabel 7.

Tabel 7

Average Variance Extracted (AVE), composite reliability ( $\rho$ c) dan Cronbach Alpha efektivitas penyaluran KUR, produktivitas UKM dan pendapatan UKM

\begin{tabular}{lccc}
\hline \multicolumn{1}{c}{ Variabel Konstruk } & $\begin{array}{c}\text { Average Variance } \\
\text { Extracted }\end{array}$ & $\begin{array}{c}\text { Composite } \\
\text { Reliability }\end{array}$ & $\begin{array}{c}\text { Cronbach } \\
\text { Alpha }\end{array}$ \\
\hline Efektivitas Penyaluran KUR(X1) & 0.704 & 0.825 & 0.793 \\
Produktivitas UKM (Y1) & 1.000 & 1.000 & 1.000 \\
Pendapatan UKM (Y2) & 1.000 & 1.000 & 1.000 \\
\hline
\end{tabular}

Sumber : Data Primer 2017 
Ni Luh Md. Ayu Danni Lastina, dan Md. Kembar Sri Budhi. Efektifitas Penyaluaran......

Berdasarkan Tabel 6 dapat diketahui bahwa efektivitas penyaluran KUR, produktivitas UKM dan pendapatan UKM bagus dan terpercaya sebagai alat pengumpulan data dalam penelitian, karena memiliki discriminant validity yang lebih besar dari 0.50 untuk Average Variance Extracted (AVE) dan composite reliability serta cronbach alpa diatas 0.7 .

Pengujian kepada model struktural bisa dilakukan dengan melihat nilai $R$ square atau uji goodness fit model. Evaluasi terhadap model struktural (Inner model) berkaitan dengan pengujian hubungan antar variabel laten yang sebelumnya telah dihipotesiskan. Kebaikan model ditunjukkan dengan menggunakan nilai $R$-Square $\left(\mathrm{R}^{2}\right)$ dan nilai $Q$-Square $\left(Q^{2}\right) . \quad R$-Square menjelaskan seberapa besar variabel eksogen yang dihipotesiskan dalam persamaan mampu menerangkan variabel endogen. Model pengujian $R$-square dapat dilihat pada Tabel 8 .

Tabel 8

Nilai $R$-Square Variabel Endogen

\begin{tabular}{lc}
\hline \multicolumn{1}{c}{ Variabel Endogen } & R-Square \\
\hline Produktivitas UKM (Y1) & 0.586 \\
Pendapatan UKM (Y2) & 0.049 \\
\hline
\end{tabular}

Sumber : Data Primer 2017

Nilai hasil olah data maka didaptkan $R$-Square variabel efektivitas sebesar 0.586 hal ini menunjukkan variabel efektivitas penyaluran KUR dapat menjelaskan sebesar 58,60 persen dari variasi variabel produktivitas UKM sedangkan sisanya sebesar 41,40 persen diterangkan oleh variabel lain di luar model. $R$-Square variabel pendapatan UKM sebesar 0.049 yang berarti bahwa variabel efektivitas penyaluran KUR dan produktivitas UKM dapat menjelaskan 
sebesar 4.9 persen dari pendapatan UKM dan sisanya 95,10 persen dijelaskan oleh variabel lain di luar model.

Uji yang kedua ialah untuk melihat signifikansi pengaruh variabel laten eksogen terhadap variabel endogen dengan melihat nilai koefisien parameter dan nilai signifikan t-statistik. Berikut hasil uji pada Tabel 9

Tabel 9

Hasil Pengujian Path Coefficients (Mean, STDEV, T-Values)

\begin{tabular}{ccccccc}
\hline & $\begin{array}{c}\text { Original } \\
\text { Sample } \\
(\mathrm{O})\end{array}$ & $\begin{array}{c}\text { Sample } \\
\text { Mean } \\
(\mathrm{M})\end{array}$ & $\begin{array}{c}\text { Standar } \\
\text { Deviation } \\
(\mathrm{STDEV})\end{array}$ & $\begin{array}{c}\text { T } \\
\text { Statistics } \\
(\mid \mathrm{O} / \mathrm{STE} \\
\mathrm{RR} \mid)\end{array}$ & $\begin{array}{c}\text { Standard } \\
\text { Error } \\
(\text { STERR }\end{array}$ & Ket \\
\hline $\begin{array}{c}\text { Efektivitas -> } \\
\text { Pendapatan }\end{array}$ & 0.719 & 0.726 & 0.040 & 18.065 & 0.031 & Signifikan \\
$\begin{array}{c}\text { Efektivitas -> } \\
\text { Produktivitas } \\
\text { Produktivitas -> } \\
\text { Pendapatan }\end{array}$ & 0.221 & 0.224 & 0.101 & 2.186 & 0.101 & Signifikan \\
\hline Sumber : Data Primer 2017 & 0.149 & 0.140 & 0.069 & 2.149 & 0.069 & Signifikan \\
\hline
\end{tabular}

Berdasarkan data pada Tabel 9 hasil uji Path Coefficients dengan PLS menunjukkan terdapat tiga hubungan antar variabel yaitu efektivitas penyaluran KUR dengan pendapatan UKM, efektivitas penyaluran KUR dengan produktivitas UKM dan produktivitas UKM terhadap pendapatan dinyatakan positif dan signifikan karena hasil pengujian diketahui nilai t-statistik lebih besar dari 1,96.

Pengaruh tidak langsung antar variabel dapat dilihat dari hasil analisis indirect effect atau pengaruh tidak langsung antar variabel dan hubungan tidak langsung variabel independen terhadap dependen atau pengaruh variabel efektivitas penyaluran KUR melalui variabel mediasi yaitu produktivitas UKM 
Ni Luh Md. Ayu Danni Lastina, dan Md. Kembar Sri Budhi. Efektifitas Penyaluaran......

terhadap variabel pendapatan UKM. Hasil pengujian pengaruh tidak langsung dapat dilihat seperti pada Tabel 10

Tabel 10

Hasil Pengujian Pengaruh Tidak Langsung

\begin{tabular}{cccc}
\hline \multirow{2}{*}{ Hubungan } & \multicolumn{3}{c}{ Pengaruh } \\
\cline { 2 - 4 } & Pengaruh Langsung & $\begin{array}{c}\text { Pengaruh Tidak } \\
\text { Langsung }\end{array}$ & Pengaruh Total \\
\hline X1 --> Y1 & 0,221 & - & 0,221 \\
y1 --> Y2 & 0,149 & - & 0,149 \\
X1 --> Y2 & 0,719 & 0.033 & 0,752 \\
\hline
\end{tabular}

Sumber : Data Primer 2017

Hasil penelitian pengaruh tidak langsung dengan melihat besar pengaruh variabel bebas efektivitas penyaluran KUR (X1) terhadap variabel terikat pendapatan UKM melalui variabel perantara produktivitas UKM yaitu sebesar 0.752. Pengaruh total menunjukkan keseluruhan nilai pengaruh variabel secara langsung maupun tidak langsung. Berdasarkan hasil analisis pengujian pengaruh total yang disajikan di dalam tabel 9 menunjukkan bahwa yaitu efektivitas penyaluran KUR berpengaruh positif dan signifikan terhadap pendapatan UKM, efektivitas penyaluran KUR berpengaruh positif dan signifikan terhadap produktivitas UKM dan produktivitas UKM berpengaruh positif dan signifikanterhadap pendapatan UKM.

Tabel 11

Pengaruh Total/Total Effect Variabel-Variabel Penelitian

\begin{tabular}{cccccc}
\hline Hubungan & $\begin{array}{c}\text { Original } \\
\text { Sample } \\
(\mathrm{O})\end{array}$ & $\begin{array}{c}\text { Sample } \\
\text { Mean } \\
(\mathrm{M})\end{array}$ & $\begin{array}{c}\text { Standard } \\
\text { Deviation } \\
(\text { STDEV })\end{array}$ & $\begin{array}{c}\text { Standard } \\
\text { Error } \\
(\text { STERR })\end{array}$ & $\begin{array}{c}\text { T Statistics } \\
(\mid \mathrm{O} / \mathrm{STERR})\end{array}$ \\
\hline Efektivitas -> Pendapatan & 0.752 & 0.759 & 0.031 & 0.031 & 24.349 \\
Efektivitas -> Produktivitas & 0.221 & 0.224 & 0.101 & 0.101 & 2.186 \\
Produktivitas -> Pendapatan & 0.149 & 0.140 & 0.069 & 0.069 & 2.149 \\
\hline
\end{tabular}

Sumber : Lampiran 3

Hasil penelitian menunjukkan bahwa efektivitas penyaluran KUR Bank

BRI Unit Blahkiuh berpengaruh positif dan signifikan terhadap produktivitas 
UKM penerima KUR di Kecamatan Abiansemal. Hal ini berarti apabila tingkat efektivitas penyaluran KUR meningkat maka produktivitas UKM juga meningkat, begitu juga sebaliknya. Penyaluran KUR tersebut dikatakan mampu dan sudah berkontribusi dalam kegiatan produksi selama jam kerja pada UKM yang ada di Kecamatan Abiansemal. Menurut Artis (2012) dimana produktivitas dari pengusaha mikro dan kecil atau anggota merupakan hal yang paling penting untuk menilai usaha tersebut mengalami peningkatan atau kemunduran, karena produksi merupakan titik tolak untuk melihat peningkatan pada saham anggota. perkembangan usaha atau UKM antara sebelum melakukan pinjaman dan sesudah melakukan pinjaman dan hal ini juga mengartikan bahwa keberadaan KUR Bank BRI unit Blahkiuh sangat mendukung dalam UKM di daerah sekitarnya.

Produktivitas ialah kemampuan faktor produksi untuk membentuk rasio diantara jumlah produksi dan jumlah faktor produksi yang dihasilkan dalam waktu tertentu. Mukaran (2000) dalam penelitiannya menyatakan bahwa produktivitas ialah kesadaran guna menghasilkan sesuatu yang lebih banyak daripada yang telah atau yang sedang berada dalam usahanya serta menambah kegiatan guna menghasilkan lebih banyak dari apa yang telah dicapai. Sedangkan menurut Dharma (2002) mengatakan bahwa produktivitas adalah suatu perbandingan dari hasil kegiatan yang senyatanya dengan hasil yang seharusnya. Peningkatan produktivitas dapat diartikan sebagai peningkatan-peningkatan hasil yang dicapai dengan penggunaan sumber daya secara efektif dan efisien hingga dapat memberikan kontribusi yang berarti bagi pertumbuhan ekonomi ke arah yang lebih baik. 
Ni Luh Md. Ayu Danni Lastina, dan Md. Kembar Sri Budhi. Efektifitas Penyaluaran......

Perkembangan UKM di Kecamatan Abiansemal merupakan sasaran dari penyaluran KUR Bank BRI Unit Blahkiuh untuk membantu dan memberikan kontribusi dalam meningkatkan produktivitas sehingga bantuan KUR yang diperoleh menjadi efektif. Menurut Yhushinta (2006) efektivitas menurut adalah adanya kesinambungan tujuan yang telah ditetapkan oleh Bank Pelaksana dengan debitur, dapat bermanfaat bagi pengusaha-pengusaha mikro (UKM) dalam mengembangkan usahanya yang ditandai dengan meningkatnya produktivitas dan pendapatan serta adanya timbal balik yang diberikan nasabah kepada Bank Pelaksana berupa pembayaran angsuran dengan tepat waktu.

Menurut Arieska (2017) Keberadaan UKM yang semakin meningkat menyebabkan UKM tidak memiliki utang di luar negeri karena sumber pendanaan dalam kegiatan usaha UKM ini banyak menggunakan bantuan perbankan dan modal sendiri. Kegiatan yang dilakukan UKM, seperti industri pengolaha, perdagangan, dan jasa menggunakan bahan baku lokal yang terdapat di dalam negerinya sendiri sehingga dapat menimbulkan multiplier effect bagi perekonomian khususnya dengan menggunakan produk lokal dapat saling mensejahterahkan (Bertola.2006). Hal tersebut menjadikan kegiatan produksi tidak bergantung pada bahan baku yang berasal dari luar negeri. Pada saat ini UKM mulai berorientasi kepada ekspor. Produk yang dihasilkan UKM mulai dilirik oleh pasar luar negeri (Ekere.2014).

Hasil penelitian menunjukkan bahwa efektivitas penyaluran KUR Bank BRI Unit Blahkiuh berpengaruh positif dan signifikan terhadap pendapatan UKM penerima KUR di Kecamatan Abiansemal. Pendapatan merupakan salah satu 
faktor terpenting dalam mengukur tingkat keberhasilan para pengusaha atau UKM. Pendapatan merupakan salah satu tujuan didirikan sebuah usaha. Dengan adanya pendapatan itu berarti sebuah usaha masih berjalan dan layak untuk dipertahankan walaupun masih ada pertimbangan untuk meneruskan sebuah usaha. Dengan adanya tambahan modal KUR dari Bank BRI Unit Blahkiuh diharapkan dapat meningkatkan pendapatan usaha para UKM di Kecamatan Abiansemal sehingga usahanya menjadi maju dan layak.

Hasil penelitian Semara (2013) mengatakan pendapatan UMKM Di Kota Denpasar lebih meningkat setelah mengikuti program kegiatan bantuan KUR PT. Bank Rakyat Indonesia (Persero) Tbk. Kanca Denpasar Gajah Mada tahun 2012. Tidak hanya itu dalam penelitian Yudha (2015) mendukung hasil penelitian ini yang menunjukan hasil yang cukup efektif dan berpegaruh signifikan dengan adanya KUR mampu meningkatkan pendapatan. Pada umumnya yang menjadi \ kendala bagi UKM adalah mengenai sumber pembiayaan. Sumber pembiayaan biasanya sangat erat hubungannya dengan peningkatan pendapatan atau disebut juga peningkatan omset.

Subudi (2010) dalam penelitiannya juga menunjukkan hasil ini sudah efektif dan berpegaruh signifikan dengan adanya program KUR yang mampu meningkatkan pendapatan. Pada umumnya yang menjadi salah satu kendala bagi UKM adalah mengenai sumber pembiayaan. Sumber pembiayaan biasanya sangat erat hubungannya dengan peningkatan pendapatan atau disebut juga peningkatan omset. 
Ni Luh Md. Ayu Danni Lastina, dan Md. Kembar Sri Budhi. Efektifitas Penyaluaran......

Setiap orang maupun anggota kelompok yang bergerak dalam bidang usaha ekonomi khususnya dagang, selalu berusaha untuk mencari pendapatan semaksimal mungkin. Dalam dunia dagang dimana untuk mendapat pendapatan yang maksimal maka perlu biaya atau modal yang memadai juga. Namun bagi pengusaha mikro dan kecil untuk mendapatkan sumber pembiayaan yang mudah dan dengan bunga rendah sangat susah (Estey.2009). Menurut Obilor (2013) pengusaha mikro dan kecil ini lebih percaya dengan modal atau sumber pembiayaan sendiri dibanding modal yang didapat dari luar, namun jika sumber pembiayaannya mengalami kekurangan maka pemilik usaha mikro dan kecil akan melakukan dan mempertimbangkan untuk melakukan pinjaman pada pihak luar, seperti pada Bank BRI Unit Blahkiuh.

Kehadiran dan peranan Bank BRI Unit Blahkiuh memberi manfaat yang sangat besar untuk membantu para pengusaha mikro dan kecil tersebut. Hal ini juga lah yang dirasakan oleh pedagang-pedagang mikro dan kecil yang juga nasabah pada Bank BRI Unit Blahkiuh. Para nasabah mengakui bahwa keberadaan koperasi sangat membantu untuk mendukung kemajuan usaha pengusaha. Bank BRI Unit Blahkiuh berbeda peranannya dengan lembaga lain karena seperti berbagai alasan nasabah di atas lembaga Bank BRI Unit Blahkiuh lebih berpihak pada pengusaha-pengusaha yang memiliki modal terbatas.

Hasil penelitian hubungan tidak langsung variabel efektivitas penyaluran KUR terhadap pendapatan UKM penerima KUR melalui produktivitas UKM di Kecamatan Abiansemal menunjukkan pengaruh positif dan signifikan. Ini berarti variabel efektivitas penyaluran KUR berpengaruh positif dan signifikan secara 
tidak langsung terhadap pendapatan UKM penerima KUR melalui produktivitas UKM di Kecamatan Abiansemal.

Produktivitas dan pendapatan sangat erat hubungannya, ketika produksi suatu barang dan jasa yang dihasilkan selama jam kerja meningkat dan menghasilkan keuntungan yang besar sehingga pendapatan akan meningkat juga. Begitu pula sebaliknya, apabila produktivitas rendah maka pendapatan yang diperoleh akan rendah (Ismael.2013).. Para pedagang dan UKM yang menerima KUR di Kecamatan Abiansemal diharapkan menggunakan KUR untuk modal usahanya secara efektif sehingga dapat meningkatkan pendapatan. Adanya peningkatan pendapatan para UKM penerima KUR di Kecamatan Abiansemal maka usahanya dapat dikembangkan menjadi lebih baik sehingga mampu mensejahterakan keluarga. Penelitian yang dilakukan oleh Tampubolon (2006) yang mengatakan bahwa kredit yang diberikan berpengaruh positif terhadap peningkatan laba usaha kecil.

Peningkatan pendapatan UKM melalui program KUR memberikan kontribusi yang cukup besar, hal tersebut dapat terlihat dari hasil observasi dan kuesioner yang mengatakan bahwa pendapatan mereka bertambah setelah mengikuti program KUR. Pelaku UKM yang mendapatkan program KUR juga mengatakan bahwa dengan adanya program ini mereka bisa menambah modal usaha mereka sehingga omset penjualan mereka pun bertambah sesuai dengan kebutuhannya melalui peningkatan produktivitas.

Menurut Ali (2014) adanya program KUR masyarakat atau UKM bisa menyisihkan hasil pendapatan yang diperoleh, melalui hasil observasi maupun 
Ni Luh Md. Ayu Danni Lastina, dan Md. Kembar Sri Budhi. Efektifitas Penyaluaran......

wawancara mereka mengatakan bahwa mereka menyisihkan sebagian pendapatan mereka untuk ditabung. Hal ini disebabkan oleh peningkatan pendapatan yang mereka dapatkan setelah mengikuti program ini.

\section{SIMPUL DAN SARAN}

Berdasarkan hasil analisis dan pembahasan sebagaimana sudah diuraikan terdahulu, maka kesimpulan yang dapat disampaikan bahwa Efektivitas penyaluran KUR Bank BRI Unit Blahkiuh $\left(\mathrm{X}_{1}\right)$ dengan menggunakan 2 indikator dari 4 indikator yaitu jenis usaha, lama usaha, pendidikan dan umur, berpengaruh positif dan signifikan terhadap produktivitas UKM $\left(\mathrm{Y}_{1}\right)$ di Kecamatan Abiansemal. Produktivitas UKM $\left(\mathrm{Y}_{1}\right)$ berpengaruh positif dan signifikan terhadap pendapatan UKM $\left(\mathrm{Y}_{2}\right)$ di Kecamatan Abiansemal. Efektivitas penyaluran KUR Bank BRI Unit Blahkiuh $\left(\mathrm{X}_{1}\right)$ berpengaruh positif dan signifikan terhadap pendapatan UKM $\left(\mathrm{Y}_{2}\right)$ melalui produktivitas UKM $\left(\mathrm{Y}_{1}\right)$ di Kecamatan Abiansemal.

Usaha kecil menengah (UKM) di Kecamatan Abiansemal perlu dilakukan sosisalisai guna untuk mencegah melakukan penyalahgunaan terhadap pemberian kredit (KUR) yang diterima, sehingga upaya yang dilakukan oleh pemerintah untuk mengangkat dan meningkatkan mutu perekonomian masyarakat dapat tercapai. BRI Unit Blahkiuh perlu meningkatkan daya serap KUR bagi nasabah dengan melakukan kegiatan pembinaan dan sosialisasi yang berkaitan dengan manajemen usaha untuk meningkatkan usahanya sehingga perealisasian terhadap KUR meningkat. Penelitian selanjutnya perlu menambah bebeapa variabel yang mempengaruhi peningkatan pendapatan dan produktivitas pengusaha kecil mikro, 
sehingga hasil penelitiannya dapat dijadikan refernsi yang lebih baik dan lebih lengkap.

\section{REFERENSI}

Ade Raselawati.2011.Pengaruh Perkembangan Usaha Kecil Menengah Terhadap Pertumbuhan Ekonomi Pada Sektor UKM di Indonesia.Jurusan Ilmu Ekonomi dan Studi Pembangunan.Fakultas Ekonomi dan Bisnis.Universitas Islam Negeri Syarif Hidayahtullah Jakarta.

Ali Imran.2014. Analisis Pengaruh Produktivitas Kelapa Sawit Terhadap Pendapatan Masyarakat Di Kecamatan Pante Cereumien.Program Studi Ilmu Ekonomi dan Studi Pembangunan Fakultas Ekonomi Universitas Teuku Umar.Meulaboh Aceh Barat.

Agus Dharma. 2002, Manajemen Prestasi Kerja, Rajawali Pers, Jakarta.

Andriani Septy. 2008. Analisis Faktor-Faktor yang Mempengaruhi Volume Penyaluran Kredit Mikro, Kecil dan Menengah (UMKM) di Indonesia. (Skripsi). Institut Pertanian Bogor

Anggiawan, Aries.2010. Analisis Efektivitas Faktor-Faktor yang Mempengaruhi Realisasi Pembiayaan Syariah pada sektor Agribisnis (StudiKasus BPRS Amanah Ummah, Bogor).Fakultas Ekonomi dan Manajemen IPB. Bogor

Anugrah Mahadi.2013. Efektivitas Penyaluran Kredit Usaha Mikro, Kecil, dan Menengah (UMKM) Sektor Agribisnis Nasabah BRI Unit Ciampea Bogor. Departemen Agribisnis Fakultas Ekonomi dan Manajemen Institut Pertanian Bogor.

Arieska Dianthy Luh Gede.2017. Dampak Program KUR Bank BRI Terhadap Pendapatan Pelaku Usaha Mikro di Pasar Kumbasari dan Pasar Kreneng Kota Denpasar. Fakultas Ekonomi dan Bisnis Universitas Udayana.

Artis Simatupang.2012. Efektivitas Kredit Usaha Rakyat Dalam Pengembangan Usaha Mikro Dan Kecil.

Asih, Mukti. 2007. Analisis Faktor-Faktor yang Mempengaruhi Pengembalian Kredit Pengusaha Kecil pada Program Kemitraan Corporate SocialResponsibilty. Skripsi. Fakultas Ekonomi dan Manajemen. Institut Pertanian Bogor. 
Ni Luh Md. Ayu Danni Lastina, dan Md. Kembar Sri Budhi. Efektifitas Penyaluaran......

Baholli, F., Dika, I., dan Xhabija, G. 2015. "Analysis of Factors that Influence Non-Performing Loans with Econometric Model: Albanian Case". Mediterranean Journal of Social Sciences, Vol. 6, No. 1, pp. 391-398.

Bertola, G., R. Disney., and C. Grand. 2006. The Economics of Consumer Credit. Massachusetts Institute of Technology.

Bonifrm, D. 2003. "Credit Risk Drivers: Evaluating The Contribution Of Firm Level Information And Macroeconomic Dynamics". Journal of Banking And Finance, Vol.33, pp: 281-299.

Chandra Adyatma I Wayan .2016. Faktor-Faktor Yang Mempengaruhi Efektivitas Penggunaan Kredit UKM Di Kota Denpasar Provinsi Bali. Universitas Udayana.

Curak, M., Pepur, S., dan Poposki, K. 2013. "Determinants of non-performing loans - evidence from Southeastern European banking systems". Banks And Bank Systems, Vol. 8, Issue 1, pp. 45-53.

Desiderius Fadliyah. 2003. Pengaruh Lingkungan Kerja Terhadap Produktivitas Kerja Karyawan PT. Fajar Mulia Pradipta, Surakarta. Surakarta : Universitas Muhammadiyah Malang.

Dinas Koperasi, UKM, Perindustrian dan Perdagangan Kabupaten Badung.2016

Dewi Anggraini dan Syahrir Hakim Nasution.2013. Peranan Kredit Usaha Rakyat (KUR) Bagi Pengembangan UMKM Di Kota Medan (Studi Kasus Bank $B R I)$.

Ekere dan Edeme. 2014. Journal, Vol 14 Issue 3. Evaluation of Agricultural Credit Facility in Agricultural Production and Rural Development, Global Journal Inc : USA

Eko Putro Mulyarto.2009. Faktor-faktor Yang Mempengaruhi Realisasi Kredit Usaha Rakyat (KUR) di Bank Rakyat Indonesia Unit Leuwiliang Kabupaten Bogor.

Estey James Arthur, 2009, Business Cycles, Their Nature, Cause, and Control Third Edition. Prentice Hall, Inc.Englewood Cliffs - USA.

Fadhilah Rahmawati dan Vincent Hadiwiyono, 2004.Analisis Waktu Tunggu Tenaga Kerja Terdidik di Kecamatan Jebres Kota Surakarta Tahun 2003.Skripsi Fakultas Ekonomi Universitas Negeri sebelas Maret, Surakarta 
Ismael, Byaruhanga. 2013. Journal Vol 1 No 6. Credit Terms, Credit Accessibility and Performance of Agricultural Cooperatives in Rwanda. JEIEFB : National University of Rwanda.

Issabella, Pratiwi Sarigih.2015. Analisis Pengaruh Modal Sendiridan Modal Pinjaman Kredit Usaha Rakyat (KUR) Terhadap Pendapatan Pengusaha UMKM Kabupaten Toba Samosir.

Heni Mahmudah.2015.Analisis Pengaruh Pemberian Kredit Usaha Rakyat (KUR) BRI Unit Laren terhadap Peningkatan Keuntungan Usaha Mikro (kecil) Di Kecamatan Laren Kabupaten Lamongan. Fakultas Ekonomi. Universitas Islam Lamongan.

Hue, N. 2015. "Non-Performing Loans: Affecting Factor for the Sustainability of Vietnam Commercial Banks". Journal of Economics and Development, Vol.17, No.1, pp. 93-106.

Jaya, I Gede Nyoman Mindra., Sumertajaya, I Made. 2008. Pemodelan Persamaan Struktural Dengan Partial Least Square. Semnas Matematika dan Pendidikan Matematika.

Jeriko Boyke Hoajahan.2014. Efektivitas Program Kredit Usaha Rakyat (KUR) Dalam Menigkatkan Kesejahteraan Masyarakat Oleh Bank Rakyat Indonesia (BRI) Di Kelurahan Harjosari Kec Medan Amplas.

Marwansyah, Mukaram, 2000, Manajemen Sumber Daya Manusia, Pusat Penerbit Administrasi Niaga, Bandung.

Obilor, Sunny Ibe. 2013. Jurnal Vol 3 No 1. The Impact of Commercial Banks' Credit to Agriculture on Agricultural Development in Nigeria: An Econometric Analysis : Nigeria

Palazuelos, Fernandez. 2008. Demand, Employment, Labor Productivity In The European Ekonomies. structural Change and Ecomic Dynamic, dio: 10.1016

Rajan, R., dan Dahl, S. 2003. Non-performing Loans and Terms of Credit of Public Sector Banks in India: An Empirical Assessment. Occasional Papers Reserve Bank of India, Vol.24, No.3, pp. 81-121

Shingjergji, A., dan Shingjergji, I. 2013. An Analysis of the Nonperforming Loans in the Albanian Banking System. International Journal of Business and Commerce, Vol. 2, No. 6, pp. 01-11. ISSN : 2225-2436.

Subudi, Agung. 2010. Efektivitas dan Dampak Program Community Based Development (CBD) Terhadap Pendapatan dan Kesempatan Kerja Rumah Tangga Miskin di Kecamatan Marga, Kabupaten Tabanan Tahun 
Ni Luh Md. Ayu Danni Lastina, dan Md. Kembar Sri Budhi. Efektifitas Penyaluaran......

2001-2007. Skripsi S1. Denpasar: Fakultas Ekonomi Universitas Udayana.

Sudaryanto dan Hanim, Anifatul. 2002. Evaluasi kesiapan UKM Menyongsong Pasar Beba sAsean(AFTA) :Analisis Perspektif dan Tinjauan Teoritis. Jurnal Ekonomi Akuntansi dan Manajemen, Vol 1 No 2, Desember 2002

Sugiyono. 2010. Metode Penelitian Kuantitatif, kualitatif, dan $R$ dan D. Bandung: Alfabeta.

Surya Pratama Putra I Gede.2012. Efektivitas Program Jamkrida dan Dampaknya Terhadap Pendapatan dan Penyerapan Tenaga Kerja.Universitas Udayana.

Semara Putra, I Gusti Alit.2013. Efektivitas Dan Dampak Program Bantuan Kredit Usaha Rakyat (KUR) Terhadap Pendapatandan Kesempatan Kerja Usaha Mikro Kecil Menengah (UMKM) Di Kota Denpasar.

Tampubolon, Mangatas. 2006. Pendidikan Pola Pemberdayaan Masyarakat Dan Pemberdayaan Partisipasi Masyarakat Dalam Pembangunan Sesuai Tuntutan Otonomi Daerah.

Tohar.2000.Membuka Usaha Kecil.Yogyakarta: Kanisius

Tracey, M. 2011. The Impact of Non-performing Loans on Loan Growth: an econometric case study of Jamaica and Trinidad and Tobago. JEL classification numbers: G21 E44, pp.01-22.

Triwibowo, Dicky. 2009. Faktor-Faktor yang Mempengaruhi Pengembalian Kredit Bermasalah oleh Nasabah di Sektor Perdagangan Agribisnis, Kasuspada BPR Rama Ganda Bogor.Skripsi S1 Manajemen agribisnis Fakultas Pertanian Institut Pertanian Bogor

Wenagama, I Wayan.2009. Peranan Usaha Kecil Dan Menengah Dalam Penyerapan Tenaga Kerjadan Tingkat Pendapatan Masyarakat Miskin Di Kecamatan Abiansemal Kabupaten Badung.

Yhushinta Hesti Anggreni.2006.Analisis Efektivitas Kredit UKM (studi kasus UKM nasabah KBMT Binaul Ummah Kelurahan Pamoyanan Bogor Selatan. Fakultas Ekonomi dan Manajemen Institut Pertanian Bogor.

Yudha Wirawan, Made dan Sudarsana Arka. 2015. Efektivitas Program Kemitraan PT Pengembangan Pariwisata Bali (PERSERO)Dan Dampaknya terhadap Pendapatan Tenaga Kerja Usaha Mikro, Kecil dan Menengah di Kabupaten Badung. Jurnal EP. 4 (10): h: 1247-1275. 